\title{
Multistakeholder environmental governance in action: REDD+ discourse coalitions in Tanzania
}

\author{
Salla Rantala $^{1,2}$ and Monica Di Gregorio ${ }^{3}$
}

\begin{abstract}
Balancing interests to achieve legitimate and effective policies is a primary and pressing challenge in countries' efforts to prepare their national reducing emissions from deforestation and forest degradation (REDD+) strategies. Using Tanzania as a country case, we investigated the most polarizing policy discourses and assessed the influence of competing discourse coalitions on the drafting of the national REDD+ strategy. We combined discourse and social network analysis to identify discourse coalitions and assess their influence. The findings indicate that the national REDD+ strategy largely reflects the positions of the discourse coalition that is controlled by powerful state actors who support central control of REDD+ financial mechanisms. The competing coalition, led by civil society organizations, has limited influence on the national strategy, despite discursive congruence and concerted political action. The findings further indicate that discursive practices and institutional rules codetermine policy outcomes.
\end{abstract}

Key Words: discourse coalitions; power; REDD+; social network analysis; Tanzania

\section{INTRODUCTION}

Reducing emissions from deforestation and forest degradation $(\mathrm{REDD}+)$ is a climate change mitigation mechanism based on the idea of rewards or incentives for the maintenance and enhancement of carbon stocks in tropical forests, the loss of which currently accounts for up to $12-20 \%$ of global greenhouse gas emissions (Van der Werf et al. 2009). The Bali Action Plan, adopted at the 13th Conference of the Parties to the United Nations Framework Convention on Climate Change in 2007, laid out the framework for countries to start preparing for a postKyoto climate change agreement involving REDD+ actions: demonstrated emission reductions through improved forest protection, sustainable forest management, and/or enhancement of carbon stocks (UNFCCC 2008). Multilateral and bilateral financial instruments to facilitate these preparations, such as the World Bank's Forest Carbon Partnership Facility, Norway's International Climate and Forest Initiative, and the United Nations REDD+ (UN-REDD) Programme, were launched. A growing number of developing countries are formulating national REDD+ strategies and policies (Angelsen et al. 2009, Kanowski et al. 2011, Den Besten et al. 2014).

For a country to meet its REDD+ targets in its specific and dynamic national context, it will require effective coordination and actions from a range of actors at national and subnational levels (Angelsen et al. 2009). These actors include governmental agencies, local communities constituting forest custodians and users, environmental and development nongovernmental organizations (NGOs), businesses in sectors that drive deforestation and forest degradation or engage in REDD+ actions, and transnational actors, such as foreign governments and intergovernmental organizations that support national REDD+ preparation. National REDD+ processes thus represent multiactor, multilevel governance (Forsyth 2009) in action, characterized by a move away from government-centered policy making toward more inclusive, participatory forms of policy formulation and implementation, driven by expectations of subsequent greater effectiveness and legitimacy of the policies (Arts 2012). However, the various actors involved are likely to differ a great deal in their interests and understanding with regard to optimal REDD+ policies, concerning such issues as the appropriate scale for accounting and benefit sharing in REDD+, environmental and social cobenefits, and participation and rights of local and indigenous communities (Angelsen et al. 2008, Forsyth 2009, Peskett and Brockhaus 2009). The extent to which different voices are heard and influence REDD+ policies will be conditioned by the agency of more or less powerful actors embedded in social and political hierarchies, coalitions and networks, and the institutions that define the rules of the game for the policy process (Arts and Buizer 2009, Peskett and Brockhaus 2009).

We analyze the struggle of organizational actors involved in formulating the national REDD+ strategy in Tanzania to promote their ideas about REDD+ challenges and appropriate solutions, and the factors that shape their influence on a key policy output, i.e., the national REDD+ strategy. The analysis is based on the premise that what constitutes appropriate mechanisms to ensure environmentally effective and socially equitable REDD+ is socially constructed, rooted in the distinctive worldviews of policy actors, and influenced by discursive contests involving deliberation, the coproduction of ideas, and argumentation (Fischer and Forester 1993, Hajer and Wagenaar 2003). We were informed by theories of discourse coalitions (Hajer 1993, 1995) and discursive institutional analysis (Arts and Buizer 2009, Den Besten et al. 2014). Our main theoretical and methodological contribution is the combination of the analysis of policy discourses, i.e., language and action used to give meaning to reality (cf. Hajer 1995), with social network measures of power relations. We also pay attention to institutional path dependencies (cf. Brockhaus et al., in press), as well as to feedback loops between discourses and institutions. Our approach allows us not only to identify distinct discourse coalitions but also to empirically assess dominance based on differential power. Our aim is to enhance understanding of policy conflict and of the influence of each group of policy actors on REDD+ policy outputs in Tanzania, thus examining the promise of multiactor governance in light of empirical data. We focus on two research questions: (1) What are the polarizing issues that characterize discourse coalitions, formed by organizational actors involved in REDD+ strategy formulation in Tanzania, and what kind of differential framing of the key challenges for REDD+ and the appropriate policy 
responses are they based on? (2) What is the influence of each discourse coalition on the national REDD+ strategy, and which factors condition their influence?

\section{METHODS}

\section{Theoretical background and approach}

Discursive approaches to environmental and forest policy analysis (cf. Fischer and Forester 1993, Hajer and Wagenaar 2003, Arts and Buizer 2009) draw attention to policy processes as contests between forms of discourse, that is, the language and practices through which meaning is given to physical and social realities, including policy problems and their potential solutions (Arts and Buizer 2009, Den Besten et al. 2014). The coexistence of distinct and competing discourses leads policy actors to form coalitions to strengthen certain discourses and constrain others (Hajer 1993, 1995, Arts and Buizer 2009). Following Hajer (1993:47), we define a discourse coalition as an "ensemble of a set of storylines, the actors that utter these storylines, and the practices that conform to these storylines." Story lines are political devices through which actors try to impose their views and perception of interests regarding a policy problem on others and to critique and constrain competing views (Hajer 1993). They are essentially narratives of the reality as constructed by social actors, who assemble frames that can be defined as "selectively encoded and punctuated objects, situations, events, experiences and sequences of actions within one's past and present environment" (Snow and Benford 1992:137). Frames may be diagnostic, i.e., identifying and attributing problems, or prognostic, i.e., identifying solutions, and they may motivate political action (Benford and Snow 2000). Politically successful story lines are said to combine all three elements, while linking facts, values, and action (Hajer and Laws 2006, Leifeld and Haunss 2012). By gaining wider acceptance, shared story lines can help reduce fragmentation and approach problem closure (Hajer 1995).

Discourse becomes institutionalized when the story lines articulated by a coalition come to be acted upon in the policy process, for instance through outputs such as policy documents (Hajer 1995). Policy texts may thus be seen as playing a mediating role between discourse and action (Phillips et al. 2004, cited in Arts and Buizer 2009). In addition to the more far-reaching role of policy texts in institutional reproduction, we consider that they may be important triggers of immediate strategic action in the policy process (cf. Den Besten et al. 2014). Draft texts in particular may offer tangible "hooks" for actors that seek to engage in the deliberative exchange to comment on and critique policy proposals and to propose alternatives. Frequently, formal solicitation of comments from actors forms an institutionalized part of the policy drafting process in the multilevel governance framework. In addition, strategic action as a response to policy proposals may be manifested through so-called protest events: "collective, public action regarding issues in which explicit concerns around [e.g., REDD+] are expressed as an important dimension, organized by non-state instigators with the explicit purpose of critique or dissent together with societal and/or political demands" (Fillieule and Jiménez 2003:273). In line with the previous conceptualization, we consider that the target of protest action may be the content of the policy proposal,i.e., story lines and/or the institutional rules that guide the policy process, governing participation in agenda setting, decision making, and resource allocation. Institutions may thus be seen as both the outputs or outcomes of policy processes that discourse coalitions respond to, forming a spiral of action, discourse institutionalization, and counteraction, as well as the boundaries that shape the action and agency of the actors involved (Den Besten et al. 2014).

Hajer (1993) suggests that the institutional practices of the policy process reflect the ideas of the dominant coalition, following the acceptance of the discourse of the dominant coalition by influential actors. This draws our attention to the power relations in the policy domain, particularly to the actors' ability to mobilize support (Arts and Buizer 2009). Influence may also indicate authority, lending legitimacy to the story lines of the dominant coalition. Leifeld and Haunss (2012) further observe that successful discourse coalitions are stable over time with regard to their core frames and actors; show high intracoalition ideational congruence; appear united against competitors, suggesting coordinated political action; attract a large constituency; dominate the core frames of a conflict; and employ the core frames effectively in consistent story lines.

\section{Study context and data collection}

The drafting of a national REDD+ strategy was begun in Tanzania in 2008 when the government established a bilateral partnership on climate change with Norway. The partnership facilitates not only the strategy development but also subnational pilot REDD+ projects and REDD+ research and capacity building. Led by the government REDD+ Task Force, the formulation of the national REDD + strategy has involved a series of stakeholder consultations, including with representatives of regional and local governments, civil society organizations (CSOs) including NGOs and the private sector, and international and multilateral actors, and it has drawn on inputs from REDD+ pilot projects and in-depth studies (http://www.reddtz.org; URT $2013 b)$.

This research was undertaken in Tanzania between March and June 2011 at the time when public consultations to solicit comments on the first draft of the national REDD+ strategy were under way. The overall research design has been described by Brockhaus and Di Gregorio (2012) and Rantala (2012).

The first step was the identification of the organizational boundaries of the REDD+ policy domain (Laumann et al. 1992) through individual consultations with 7 experts involved in the national REDD+ initiative. Those organizations mentioned at least 4 times were considered relevant REDD+ policy actors. A departure from this criterion was the inclusion of 3 domestic business organizations (consultants) because of their known formal role in the policy process. One organization that declined having any interest in the national REDD+ process, despite being mentioned by the expert panel, was excluded. Representatives of 53 organizations out of the identified $56(95 \%)$ that normally represented their organizations in the national REDD+ process responded to a structured survey. Semistructured, qualitative interviews were conducted with 41 of these organizational actors, either with the same representative or a higher-ranking official who could plausibly represent the position of the whole organization. 
In our mixed-methods approach (cf. Edwards 2010), we drew on 3 sources of information to identify the core competing discourses of the policy debate: the organizational survey, semistructured interviews, and public statements released by policy actors. In the survey, respondents indicated the position of their organization, i.e., agree/disagree/neutral/no knowledge, with regard to 35 predefined stances on REDD+ design, challenges, and governance drawn from the existing literature on REDD+ policy debates. We analyzed the distribution of the responses to identify the stances on which the respondents' opinions were the most divided, i.e., a high number of both agreement and disagreement responses. Analysis of transcribed qualitative interview data and of public statements, i.e., policy briefs, reports, and feedback documents, by some of the actors (TFWG 2009, 2010, TFCG et al. 2010, 2012, REDD Pilot Projects 2011, TFCG and MJUMITA 2011), coded using computer-assisted qualitative data analysis freeware, deepened our understanding of the divergent frames and story lines regarding key REDD+ challenges and appropriate solutions and determined the identification of the most polarizing policy issues. Membership in a discourse coalition was also assigned based on the 3 sources of data: according to the organization's position on the contentious stances as expressed in the survey and based on triangulation with the qualitative interview and document data. For instance, if an actor indicated a neutral position on the key survey stance but clearly sided with one of the core conflict discourses in the qualitative interview data and/or a related public statement, that actor was assigned to a coalition based on the latter source. Conversely, if an actor agreed or disagreed with the survey stance, but the other data did not support this position, that actor would not be assigned to a coalition. For most actors, however, the 3 sources of data were aligned to support a similar classification.

The survey and the semistructured interviews also solicited information regarding actions taken by organizations with the aim of influencing policy, including participation in protest events identified by the expert panel. The public statements that were included in the analysis of the core discourses were frequently released as part of the protest events.

We constructed a two-mode discourse network that depicts policy actors, i.e., first-mode nodes, and their position on the contentious stances in the survey, i.e., second-mode node (Fig. 1; Borgatti and Everett 1997, Fisher et al. 2013). The ties between first- and second-mode nodes represent either agreement or disagreement with the stances. In addition, data on the reputational power of policy actors (Knoke et al. 1996, Hirschi et al. 2013) were collected through the following survey question: "Please indicate those organizations that stand out as especially influential on domestic REDD+ policies." Respondents selected organizations from the list of all policy actors identified as being part of the REDD+ policy domain and included in the survey. Following existing literature on reputational power, we used the indegree centrality measure in social network analysis to ascertain actors' level of influence (Laumann et al. 1977, Kriesi et al. 2006, Fischer et al. 2009). The influence of discourse coalitions was measured by the average of normalized indegrees of coalition members (Freeman 1978-1979, Borgatti et al. 2002). Normalized indegree centrality of an actor is the proportion of the actual mentions, i.e., incoming ties, of an actor divided by all possible incoming ties (Scott 2000). In other words, it measures how often a policy actor has been mentioned as influential in relation to all possible nominations. The higher the measure of indegree centrality, the more influential an actor is. As part of the broader study, we also asked the actors to name organizational partners in information exchange related to REDD+. There was a significant positive correlation between actor centrality in networks of information exchange and of influence (Rantala 2012), supporting the use of the reputational power measure to indicate influence.

A key limitation of the study was that we collected interview data at only one point in time, so we could not investigate changes in actor discourses and influence over time. The temporal dimension was instead addressed by comparing policy outputs, namely the national REDD+ strategy drafts, produced at different points in time with the frames and story lines of the discourse coalitions as evidence of discourse institutionalization. The policy outputs included the first (December 2010; URT 2010) and second (June 2012; URT 2012) draft national REDD+ strategies and a revised summary from November 2011 (URT 2011), as well as the final strategy dated February 2013 (URT 2013b). One coder, the first author, coded the qualitative interview data and all the documents.

\section{RESULTS}

The organizational composition of the REDD+ policy actors interviewed in 2011 is presented in Table 1 . Government executive departments and domestic NGOs were the most represented policy actors in Tanzania.

Table 1. Organizational composition of the REDD+ policy actors in Tanzania in 2011 .

\begin{tabular}{|c|c|c|}
\hline Organization type & No. actors & $\%$ \\
\hline $\begin{array}{l}\text { Government executive departments, } \\
\text { ministries }\end{array}$ & 15 & 28 \\
\hline Domestic NGOs & 14 & 26 \\
\hline International NGOs & 7 & 13 \\
\hline Multilateral organizations & 5 & 9 \\
\hline Foreign government agencies, embassies & 4 & 8 \\
\hline $\begin{array}{l}\text { Domestic academic and research } \\
\text { institutes }\end{array}$ & 4 & 8 \\
\hline Domestic businesses & 3 & 6 \\
\hline Transnational business & 1 & 2 \\
\hline Total & 53 & 100 \\
\hline
\end{tabular}

\section{Discourse coalitions}

Organizational positions in the survey data signaled high consensus among actors on most issues. Nearly $70 \%$ of the respondents considered REDD+ an effective policy instrument for mitigating greenhouse gas emissions globally. Eighty-six percent of the policy actors agreed that REDD+ needed to deliver environmental and social cobenefits, especially for the rural poor at the forest margins. The main challenges for REDD+ were considered low levels of REDD+ knowledge and capacity at all levels of governance; poor vertical and horizontal, i.e., sectoral, coordination; and competing economic interests related to agriculture and charcoal production. These challenges were regarded as barriers to achieving an effective and equitable national REDD+ strategy. 
Fig. 1. Position of policy actors on a polarizing statement on REDD+ financial flows in Tanzania. Agreement = solid line; disagreement $=$ dashed line. The size of a node represents the influence of the actor (normalized in-degree centrality of influence data). Note: Coalition membership was triangulated through the qualitative data and was not solely based on the position on the particular survey question visualized in the graph (see "Methods"), explaining the indicated coalition boundaries. Organizations outside of the coalition boundaries as indicated in the figure were considered neutral.

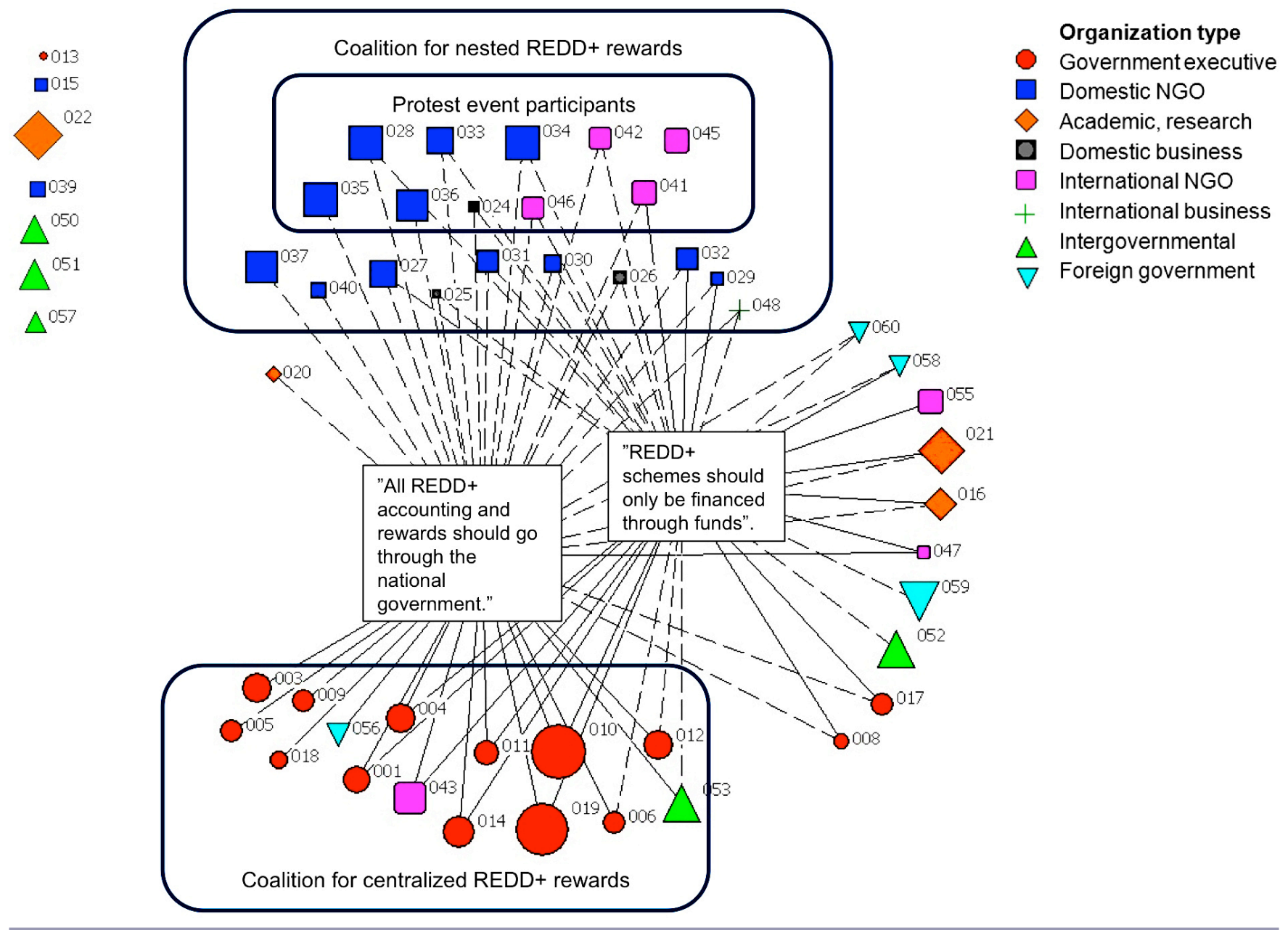

One issue was clearly characterized by divergent views as evidenced by both the quantitative and qualitative data: how to administer REDD+ financial flows and compensation. Operational structures of REDD+ may function at various scales of accounting and crediting, the options including the following: a fully national approach, implying central government control over accounting and distribution of REDD+ benefits; subnational, e.g., project-based, accounting and payments directly from international sources; or a nested approach combining the two (Angelsen et al. 2008). We identified two main discourse coalitions in the Tanzanian REDD+ policy domain in relation to the administration of financial flows: one supporting a centralized, government-controlled system of REDD+ finance and compensation through a national REDD+ trust fund, and the other rejecting it in favor of a nested approach. However, not all the actors could be unequivocally assigned to one of these two coalitions. One-third of the organizational actors presented a neutral position toward a fully national approach, including research and multilateral organizations and foreign government agencies, or were not familiar enough with the issue to have an informed opinion, i.e., certain government organizations (Table 2). Figure 1 depicts the positions of the two discourse coalitions vis-à-vis the two divisive stances related to how to administer REDD+ financial flows and compensation in the survey data. The stances read: "REDD schemes should only be financed through funds," associated by the Tanzanian respondents with the national trust fund proposal, and "all REDD accounting and payments should go through the national governments." Both were among the 5 most divisive stances out of the 35 investigated (Appendix 1).

\section{Story lines}

The qualitative data analysis revealed how contrasting diagnostic frames related to governance and tenure were interwoven with ostensibly similar motivations to promote REDD+ in the actors' story lines. This led the two coalitions to promote distinct policy 
Table 2. Centrality of REDD+ discourse coalitions and their core organizational members, measured as the normalized indegree of perceived influence.

\begin{tabular}{|c|c|c|c|}
\hline & $\begin{array}{l}\text { Coalition for centralized } \\
\text { REDD+ rewards }(n=15)\end{array}$ & $\begin{array}{l}\text { Coalition for nested REDD+ } \\
\text { rewards, community tenure and } \\
\text { safeguards }(\mathrm{n}=20)\end{array}$ & $\begin{array}{l}\text { Neutral/no knowledge } \\
(\mathrm{n}=18)\end{array}$ \\
\hline Members & $\begin{array}{l}\text { Government agencies (12) } \\
\text { International NGO (1) } \\
\text { Multilateral org. (1) } \\
\text { Foreign government (1) }\end{array}$ & $\begin{array}{l}\text { National NGOs (12) } \\
\text { International NGOs (4) } \\
\text { Domestic businesses (3) } \\
\text { International business (1) }\end{array}$ & $\begin{array}{l}\text { Government agencies (3) } \\
\text { Academic \& research inst. (4) } \\
\text { National NGO (2) } \\
\text { International NGO (2) } \\
\text { Multilateral org. (4) } \\
\text { Foreign government (3) }\end{array}$ \\
\hline Core members & $\begin{array}{l}\text { Task Force members in } 2011 \\
(\mathrm{n}=3)\end{array}$ & $\begin{array}{l}\text { Protest event leaders } \\
(\mathrm{n}=10)\end{array}$ & \\
\hline Mean centrality & 46.03 & 32.50 & 35.26 \\
\hline Median centrality & 44.23 & 31.73 & 29.81 \\
\hline $\begin{array}{l}\text { Mean centrality, core } \\
\text { members only }\end{array}$ & 75.00 & 39.42 & \\
\hline
\end{tabular}

Note: Normalized indegree of perceived influence calculated as the average proportion of actual incoming ties in relation to all possible incoming ties.

proposals regarding REDD+ financial flows. Actors strongly in favor of central government control over REDD+ finances were predominantly government agencies (Fig. 1). The core members of this coalition included the most influential actors in the REDD+ policy domain (Table 2): the state forestry and environment departments. Together with the forestry agency of Zanzibar, they formed the national REDD+ Task Force in 2011. The idea of pooling all REDD+ funding, i.e., publicly and privately sourced, and administering it through a REDD+ trust fund was a central feature in the discourse of the task force members. They framed REDD+ as primarily an opportunity to channel funding to government programs in sustainable resource management: "What we are failing to do now, we can do [it] with REDD+" (forestry officer, April 2011). In addition to the perceived environmental benefits, they saw central coordination as necessary for a fair REDD+ benefit-sharing mechanism, suggesting that the government is in the best position to oversee the equitable distribution of benefits and to protect unprepared rural communities from the tricky business of carbon trading.

In contrast, the main concern of the coalition for nested rewards was that the national trust fund would prevent benefits from reaching those who would bear most of the costs of REDD+ policies, i.e. local communities, thus jeopardizing both the social equity and the environmental effectiveness of REDD+. The core organizations in this coalition were CSOs, i.e., domestic and international NGOs and a private business, implementing REDD+ pilot projects in different parts of the country, many with a long history of involvement in the Tanzanian forestry and natural resource sectors. This coalition supported a national scheme for REDD+ accounting, to avoid leakage, i.e., displacement of deforestation from areas under REDD+ to surrounding areas, coupled with a benefit-sharing system that provided for direct subnational disbursement of rewards. Their story lines evolved around frames of ineffective and unfair centralized benefit sharing based on previous negative experiences of public sector financial management in Tanzania. For example:

We think there should be a national accounting system.
But what we're opposed to is a national reward system.
And the reason being that there's no history in Tanzania
of the national government capturing basically rewards
from natural resources at the national level, and then
taking them to communities. (domestic NGO
representative, March 2011)

According to the CSOs, decentralization of forestry, land, and wildlife management had largely failed to meet expectations of improved access to benefits from natural resources for local communities and of increased management effectiveness. They feared that REDD+ would repeat that experience. For instance, guidelines on benefit sharing from Joint Forest Management, involving community management of government forest reserves, were still pending treasury approval 13 years into the implementation of the Forest Policy (1998) that introduced Joint Forest Management (S. Rantala, personal observation).

In the interviews and public statements, CSO coalition members emphasized the need to clarify land, forest, and carbon tenure rules as a prerequisite for developing equitable systems of REDD+ benefit sharing. Progressive on paper, the implementation of the land and forest reforms was significantly slowed down by complex procedures of land registration, the absence of which impeded government recognition of vast areas of village land. This formal land category was introduced as part of the Village Land Act of 1999 to secure rural communities' land rights and subsequently their rights to resources on that land. The government officials who were interviewed considered unregistered community lands as general land, a residual category under the control of the central government (cf. URT 2010), and in practice open access, particularly susceptible to deforestation. 
In contrast, according to the CSOs, the key to bringing more forests under sustainable management was more straightforward recognition of community tenure, enabling local village communities to manage resources on village land and access benefits, including those related to REDD+ (cf. TFCG and MJUMITA 2011). Another demand by the CSO coalition, stemming from the first two concerns, was the creation and implementation of socioeconomic and environmental safeguards as part of the REDD+ monitoring system, which would ensure that local people who incur the opportunity costs of REDD+ receive adequate compensation and that activities to enhance forest carbon stocks are in line with other environmental benefits, such as biodiversity conservation.

\section{Action}

Membership in the CSO discourse coalition was associated with participation in protest events. In late 2010 and early 2011, Tanzanian CSOs became concerned about delays in the national REDD+ strategy development, which in their view had become an increasingly closed process centered on the REDD+ Task Force. They organized public debates on REDD+ and submitted comments on the draft national REDD+ strategy and the Tanzanian Readiness Preparation Proposal for the World Bank's Forest Carbon Partnership Facility. Through this strategic action, the CSOs established their position in the policy arena, and, by the time the current study was conducted, the core members of this coalition, i.e., those leading the five major protest events identified by the expert panel, were considered among the most influential policy actors in Tanzania (Fig. 1, Table 2). The public statements of this coalition consistently highlighted the risks of a centralized benefit-sharing mechanism, the urgency of land and forest tenure clarification, and the need to ensure social and environmental safeguards (TFWG 2009, 2010, TFCG et al. 2010, 2012, REDD Pilot Projects 2011, TFCG and MJUMITA 2011). The CSO coalition thus exhibited some of the suggested characteristics of a successful discourse coalition (Leifeld and Haunss 2012): stability and consistency of core actors and frames throughout the protest events, ideational congruence among core actors, and a united front against competitors.

In contrast, the discourse of the key government actors about the operationalization of policy measures on the social equity and environmental benefits of REDD+, which they, too, said they were striving for, remained vague and ambiguous. Despite a number of in-depth studies on various aspects of REDD+ that had already been commissioned by the task force (cf. URT 2013b), they stated that a multitude of open questions remained, and more studies were needed to inform the development of the REDD+ structures. From the CSO coalition point of view, the avoidance of presenting concrete measures formally and publicly presented a major challenge to engaging the government actors in meaningful deliberative exchange.

\section{Influence}

Table 2 presents the average indegree centrality measures of the perceived influence for the two discourse coalitions. The neutral actors have also been grouped for comparison. The values indicate higher reputational power of the government-dominated coalition and especially of the national REDD+ Task Force. Considering the core members of the CSO coalition only, we see that their reputational power is relatively high but still does not match that of the government-dominated coalition.

\section{Policy outputs}

In addition to the comparison of the various versions of the national REDD+ strategy (URT 2010, 2011, 2012, 2013b), changes in the key REDD+ support structures observed in early 2012 provided some evidence of the impacts of the discourse coalitions on the policy process and its outputs. In response to public demand, the national REDD+ Task Force was expanded to include 10 new government organizations and $1 \mathrm{CSO}$. This $\mathrm{CSO}$ was one of the protest event leaders and among the 10 most influential actors of the policy domain (Fig. 1). In addition, 5 thematic working groups were established to provide technical advice for the national REDD+ strategy development, including government, research, private sector, and CSOs (URT 2013b).

Regarding the contentious issue of the administration of REDD+ rewards, all versions of the national REDD+ strategy emphasize the need for an equitable and transparent benefit-sharing system. The centerpiece of such a system is invariably stated to be the national REDD+ trust fund, in line with the discourse of the government-dominated coalition. The final strategy document (URT 2013b) details a plan for establishing a nested baseline for accounting, but no options for subnational crediting are mentioned.

Parallel to the CSO discourse, the strategy documents repeatedly refer to the threat that unclear land and forest tenure poses to fair REDD+ benefit sharing and are explicit about the link between the two, although carbon rights are not specified. In what seems to be a victory for the CSO coalition, the final strategy written in 2013 includes a reversal of the statement contained in the previous versions (URT 2010, 2011, 2012) that unregistered village land is general land; instead, it cites Ministry of Lands, Housing and Human Settlement Development data that $70 \%$ of land in Tanzania is village land and only $2 \%$ general land (URT 2013b). Later, however, this view is contradicted with a repetition of the statement in previous drafts: "The forest resources in the unreserved or general land ( $57 \%$ of area) are open access resources due to unclear ownership, absence of security of tenure and formal user rights" (URT 2013b:27). The notion that the formal recognition of communities' land and forest tenure for access to REDD+ benefits requires resource-intensive village land-use planning is retained in the 2013 strategy and a related action plan (URT 2013a), in contrast to the CSO demands.

Another central feature of the CSO discourse, social and environmental safeguards, was barely mentioned in the first draft strategy from 2010 but gained greater salience in subsequent drafts. In their comments on the second draft of 2012, the CSOs still signaled frustration about the lack of specificity regarding steps to develop and enforce the safeguards (TFCG et al. 2012). In the final version of 2013, a whole chapter is dedicated to the development of safeguards, thus recognized as an integral part of REDD+ monitoring, reporting, and verification. It is also the subject of one of the technical working groups.

\section{DISCUSSION}

The focus of the REDD+ policy debate in Tanzania and the dividing line between the identified discourse coalitions closely reflects those that may be observed in global REDD+ debates (Den Besten et al. 2014). The rights and well-being of local communities are pitted against government-led approaches to REDD+ in fear of recentralization of forest governance and appropriation of REDD+ benefits by the state (e.g., Griffiths 
2009, Phelps et al. 2010). At the same time, global REDD+ negotiations are leaning strongly toward a national approach for reasons of environmental effectiveness, namely avoiding leakage, and respect of national sovereignty (Wertz-Kanounnikoff and Angelsen 2009). In specific country contexts, REDD+ design considerations may link to previous, entrenched debates about benefit sharing in natural resource governance. Should REDD+, as a potential new source of funding, be used to strengthen weak state governance or channeled directly to local communities as compensation for the opportunity costs of forest conservation, which they may not have been able to access previously? Frequently, in these debates, CSOs emerge or are portrayed as "defenders" of local forest-dependent communities (cf. http:// www.redd-monitor.org).

A closer look at the story lines and influence of the discourse coalitions within the institutional setting of the REDD+ strategy process explains why the CSO coalition appeared successful in promoting some of its key proposals, but not all. The safeguards discourse is enjoying such attention, support, and legitimacy in global REDD+ policy discussions (e.g., UNFCCC 2011, cf. review by Mwayafu and Kisekka 2012) that it enables a prosafeguards coalition to broaden the constituency of its discourse considerably beyond the national policy arena, including intergovernmental supporters of the national REDD+ processes such as the UN-REDD Programme (Peskett and Todd 2013). The same does not apply to the issue of national versus nested REDD+ reward systems because nested approaches are mostly considered a temporary phase in the process toward national systems (Wertz-Kanounnikoff and Angelsen 2009). Enabled by higher reputational power and a formal institutional position as the leaders of the REDD+ strategy development process, ultimately deciding the strategy content, the task forceled coalition could easily hold on to the REDD+ trust fund approach.

An interesting feature of the Tanzanian REDD+ policy debate is the ambiguity of the discourse of the government actors, also reflected in the strategy texts, which members of the opposing coalition considered to be an obstacle to meaningful deliberative exchange. Although clear and concise story lines have been considered conducive for gaining dominance and discursive institutionalization (Leifeld and Haunss 2012), strategic avoidance of concise statements and hiding behind a discourse of ambiguity may be an effective means to fend off competing discourses and more open and reflexive deliberation on the pros and cons of each approach. This was perhaps illustrated in the treatment of the tenure issue in the policy process. The global push for decentralization of forest and natural resource governance (e.g., Colfer et al. 2008, German et al. 2010, Larson et al. 2010) resonates with the discourse of the CSO coalition, but effectively implemented tenure reform will clearly have profound impacts on government power bases. Grainger and Konteh (2007) note how the subtle use of ambiguity by policy makers has proved effective in resisting foreign influence. Nonetheless, ambiguity in REDD+ can in part be linked to uncertainty about the future global architecture of REDD+, the demand for verified emission reductions, and corresponding payments, which will affect the national arrangements as well.

\section{CONCLUSION}

This analysis of the REDD+ policy discourse coalitions in Tanzania has demonstrated that discursive policy analysis provides useful insights into the dynamics of REDD+ policy processes and the influence of various policy coalitions on policy decisions. As such, it helps to scrutinize the expectations of greater effectiveness and legitimacy attached to multiactor, multilevel governance. Although a number of actors formally took part in the drafting of the national REDD+ strategy, the output reflected mostly the discourse of the dominant government-centered coalition. The dominance of the government coalition was essentially related to its positional power enabled by the relevant institutional structures. Although the CSO coalition conformed to some of the characteristics of a dominant coalition in other contexts, i.e., stable and consistent messages by key actors with high ideational congruence and united, concerted political action (Leifeld and Haunss 2012), it clearly came second in the contest for discourse institutionalization. In sum, combining discursive explanations with structural or resource-oriented policy analysis may strengthen the explanatory power of both (Leifeld and Haunss 2012). The particular value of this approach lies in helping to explain why conflict persists even when actors pursue seemingly similar objectives, such as environmentally effective and socially equitable REDD+ policies.

Responses to this article can be read online at: http://www.ecologyandsociety.org/issues/responses. $\mathrm{php} / 6536$

\section{Acknowledgments:}

This research is part of the policy component of CIFOR's Global Comparative Study on REDD+ (http://www. forestsclimatechange. org/global-comparative-study-on-redd.html). The methods applied in this study build partially on research undertaken by the Comparing Climate Change Policy Networks program (http:II compon.org), funded by the National Science Foundation. We would like to thank the interviewees, Riziki Shemdoe, and Research for Poverty Alleviation (REPOA) in Tanzania for collaboration with the study. Support by the Sustainability Science Program at Harvard Kennedy School, Fulbright Center, and the Finnish Cultural Foundation is gratefully acknowledged. CIFOR's research and communication teams played highly supportive roles for the research and editing. We thank the guest editors of this issue, Maria Brockhaus and Rachel Carmenta, as well as two anonymous reviewers for their valuable comments. Funding for the CIFOR project was provided by the Norwegian Agency for Development Cooperation, the Australian Agency for International Development, the UK Department for International Development, the European Commission, the Ministry for Foreign Affairs of Finland, the David and Lucile Packard Foundation, the Program on Forests, and the U.S. Agency for International Development.

\section{LITERATURE CITED}

Angelsen, A., M. Brockhaus, M. Kanninen, E. Sills, W. D. Sunderlin, and S. Wertz-Kanounnikoff, editors. 2009. Realising 
REDD+: national strategy and policy options. Center for International Forestry Research (CIFOR), Bogor, Indonesia.

Angelsen, A., C. Streck, L. Peskett, J. Brown, and C. Luttrell. 2008. What is the right scale for REDD? Pages 31-40 in A. Angelsen, editor. Moving ahead with REDD: issues, options and implications. Center for International Forestry Research (CIFOR), Bogor, Indonesia.

Arts, B. 2012. Forests policy analysis and theory use: overview and trends. Forest Policy and Economics 16:7-13. http://dx.doi. org/10.1016/j.forpol.2010.12.003

Arts, B., and M. Buizer. 2009. Forests, discourses, institutions: a discursive-institutional analysis of global forest governance. Forest Policy and Economics 11:340-347. http://dx.doi. org/10.1016/j.forpol.2008.10.004

Benford, R. D., and D. A. Snow. 2000. Framing processes and social movements: an overview and assessment. Annual Review of Sociology 26:611-639. http://dx.doi.org/10.1146/annurev.soc.26.1.611

Borgatti, S. P., and M. G. Everett. 1997. Network analysis of 2mode data. Social Networks 19:243-269. http://dx.doi. org/10.1016/S0378-8733(96)00301-2

Borgatti, S. P., M. G. Everett, and L. C. Freeman. 2002. Ucinet for Windows: software for social network analysis. Harvard Analytic Technologies, Cambridge, Massachusetts, USA.

Brockhaus, M., and M. Di Gregorio. 2012. A brief overview: component 1 on national REDD+ policies and processes. CIFOR Infobrief 13, Center for International Forestry Research (CIFOR), Bogor, Indonesia.

Brockhaus, M., M. Di Gregorio, and S. Mardiah. In press. Governing the design of national REDD+: an analysis of the power of agency. Forest Policy and Economics. http://dx.doi. org/10.1016/j.forpol.2013.07.003

Colfer, C. J. P., G. R. Dahal, and D. Capistrano, editors. 2008. Lessons from forest decentralization: money, justice and the quest for good governance in Asia-Pacific. Earthscan, London, UK.

Den Besten, J. W., B. Arts, and P. Verkooijen. 2014. The evolution of REDD+: an analysis of discursive-institutional dynamics. Environmental Science \& Policy 35:40-48. http://dx.doi. org/10.1016/j.envsci.2013.03.009

Edwards, G. 2010. Mixed-method approaches to social network analysis. ESRC National Centre for Research Methods Review Paper NCRM/015, University of Manchester, Manchester, UK.

Fillieule, O., and M. Jiménez. 2003. The methodology of protest event analysis and the media politics of reporting environmental protest events. Pages 258-279 in C. Rootes, editor. Environmental protest in Western Europe. Oxford University Press, Oxford, UK.

Fischer, M., A. Fischer, and P. Sciarini. 2009. Power and conflict in the Swiss political elite: an aggregation of existing network analyses. Swiss Political Science Review 15:31-62. http://dx.doi. org/10.1002/j.1662-6370.2009.tb00122.x

Fischer, F., and J. Forester, editors. 1993. The argumentative turn in policy analysis and planning. Duke University Press, Durham, North Carolina, USA. http://dx.doi.org/10.1215/9780822381815
Fisher, D. R., J. Waggle, and P. Leifeld. 2013. Where does political polarization come from? Locating polarization within the U.S. climate change debate. American Behavioral Scientist 57:70-92. http://dx.doi.org/10.1177/0002764212463360

Forsyth, T. 2009. Multilevel, multiactor governance in REDD+: participation, integration and coordination. Pages 113-122 in A. Angelsen, M. Brockhaus, M. Kanninen, E. Sills, W. D. Sunderlin, and S. Wertz-Kanounnikoff, editors. Realising REDD+: national strategy and policy options. Center for International Forestry Research (CIFOR), Bogor, Indonesia.

Freeman, L. C. 1978-1979. Centrality in social networks: conceptual clarification. Social Networks 1:215-239. http://dx. doi.org/10.1016/0378-8733(78)90021-7

German, L. A., A. Karsenty, and A.-M. Tiani. 2010. Governing Africa's forests in a globalized world. Earthscan, London, UK.

Grainger, A., and W. Konteh. 2007. Autonomy, ambiguity and symbolism in African politics: the development of forest policy in Sierra Leone. Land Use Policy 24:42-61. http://dx.doi. org/10.1016/j.landusepol.2005.09.001

Griffiths, T. 2009. Seeing “REDD”? Forests, climate change mitigation and the rights of indigenous peoples and local communities. Forest Peoples Programme (FPP), Moreton-inMarsh, UK.

Hajer, M. A. 1993. Discourse coalitions and the institutionalization of practice: the case of acid rain in Great Britain. Pages 43-76 in F. Fischer and J. Forester, editors. The argumentative turn in policy analysis and planning. Duke University Press, Durham, North Carolina, USA.

Hajer, M. A. 1995. The politics of environmental discourse: ecological modernization and the policy process. Clarendon, Oxford, UK.

Hajer, M., and D. Laws. 2006. Ordering through discourse. Pages 249-266 in M. Moran, M. Rein, and R. E. Goodin, editors. The Oxford handbook of public policy. Oxford University Press, Oxford, UK.

Hajer, M. A., and H. Wagenaar, editors. 2003. Deliberative policy analysis: understanding governance in the network society. Cambridge University Press, Cambridge, UK. http://dx.doi. org/10.1017/CBO9780511490934

Hirschi, C., A. Widmer, S. Briner, and R. Huber. 2013. Combining policy network and model-based scenario analyses: an assessment of future ecosystem goods and services in Swiss mountain regions. Ecology and Society 18(2): 42. http://dx.doi.org/10.5751/ ES-05480-180242

Kanowski, P. J., C. L. McDermott, and B. W. Cashore. 2011. Implementing REDD+: lessons from analysis of forest governance. Environmental Science \& Policy 14:111-117. http:// dx.doi.org/10.1016/j.envsci.2010.11.007

Knoke, D., F. U. Pappi, J. Broadbent, and Y. Tsujinaka. 1996. Comparing policy networks: labor politics in the U.S., Germany, and Japan. Cambridge University Press, Cambridge, UK. http:// dx.doi.org/10.1017/CBO9781139174497 
Kriesi, H., S. Adam, and M. Jochum. 2006. Comparative analysis of policy networks in Western Europe. Journal of European Public Policy 13:341-361. http://dx.doi.org/10.1080/13501760500528803

Larson, A. M., D. Barry, G. R. Dahal, and C. J. P. Colfer, editors. 2010. Forests for people: community rights and forest tenure reform. Earthscan, London, UK.

Laumann, E. O., P. V. Marsden, and J. Galaskiewicz. 1977. Community-elite influence structures: extension of a network approach. American Journal of Sociology 83:594-631. http://dx. doi.org/10.1086/226596

Laumann, E. O., P. V. Marsden, and D. Prensky. 1992. The boundary specification problem in network analysis. Pages 61-87 in L. C. Freeman, D. R. White, and A. K. Romney, editors. Research methods in social network analysis. Transaction, New Brunswick, New Jersey, USA.

Leifeld, P., and S. Haunss. 2012. Political discourse networks and the conflict over software patents in Europe. European Journal of Political Research 51:382-409. http://dx.doi.org/10.1111/ j.1475-6765.2011.02003.x

Mwayafu, D. M., and J. W. Kisekka. 2012. Promoting and implementing REDD+ safeguards at national level in East Africa. REDD-net, Overseas Development Institute, London, UK. [online] URL: http://theredddesk.org/sites/default/files/resources/ pdf/2012/promoting safeguards east africa.pdf

Peskett, L., and M. Brockhaus. 2009. When REDD+ goes national: a review of realities, opportunities and challenges. Pages 25-43 in A. Angelsen, M. Brockhaus, M. Kanninen, E. Sills, W. D. Sunderlin, and S. Wertz-Kanounnikoff, editors. Realising REDD+: national strategy and policy options. Center for International Forestry Research (CIFOR), Bogor, Indonesia.

Peskett, L., and K. Todd. 2013. Putting REDD+ safeguards and safeguard information systems into practice. Policy Brief, UNREDD Programme Secretariat, Geneva, Switzerland.

Phelps, J., E. L. Webb, and A. Agrawal. 2010. Does REDD+ threaten to recentralize forest governance? Science 328:312-313. http://dx.doi.org/10.1126/science.1187774

Phillips, N., T. B. Lawrence, and C. Hardy. 2004. Discourse and institutions. Academy of Management Review 29:635-652. http:// dx.doi.org/10.5465/AMR.2004.14497617

Rantala S. 2012. Knowledge and brokerage in REDD+ policy making: a policy networks analysis of the case of Tanzania. Sustainability Science Program Working Paper No. 2012-03, Sustainability Science Program, Kennedy School of Government, Harvard University, Cambridge, MA; and Center for International Forestry Research (CIFOR), Bogor, Indonesia.

REDD Pilot Projects. 2011. Feedback on the Tanzania national REDD strategy. Tanzania Natural Resource Forum, Arusha, Tanzania. [online] URL: http://www.tnrf.org/files/FEEDBACK\% 20First $\% 20$ Draft $\% 20$ National $\% 20$ REDD $\% 20$ Strategy $\% 20$ from $\%$ 20REDD $\% 20$ Pilot $\% 20$ Projects.pdf

Scott, J. 2000. Social network analysis: a handbook. Second edition. Sage, London, UK.
Snow, D. A., and R. D. Benford. 1992. Master frames and cycles of protest. Pages 133-155 in A. D. Morris and C. M. Mueller, editors. Frontiers in social movement theory. Yale University Press, New Haven, Connecticut, USA.

Tanzania Forest Conservation Group (TFCG) and MJUMITA. 2011. A one-step guide to making the national REDD strategymore pro-poor. Policy Brief. TFCG, Dar es Salaam, Tanzania. [online] URL: http://www.tfcg.org/pdf/MJUMITA $\% 20$ and $\% 20$ TFCG $\%$ 20Policy $\%$ 20Brief $\% 20$ on $\% 20$ Land $\% 20$ Issues $\% 20$ and $\% 20$ REDD. pdf

Tanzania Forest Conservation Group (TFCG), Wildlife Conservation Society, Mpingo Conservation and Development Initiative, MJUMITA, CARE, TaTEDO, Tanzania Natural Resource Forum, and Lawyers' Environmental Action Team. 2010. Recommendations from Tanzanian civil society with regard to Tanzania's readiness preparation proposal to the forest carbon partnership facility. TFCG, Dar es Salaam, Tanzania. [online] URL: http://www.forestcarbonpartnership.org/sites/

forestcarbonpartnership.org/files/Documents/PDF/Oct2010/PC $\%$ 203c $\% 20$ Tanzania $\% 20$ R-PP $\% 20$ CSO $\% 20$ Recommendations.pdf

Tanzania Forest Conservation Group (TFCG), Wildlife Conservation Society, Mpingo Conservation and Development Initiative, MJUMITA, the Jane Goodall Institute, African Wildlife Foundation, CARE, TaTEDO, and Tanzania Natural Resource Forum. 2012. Recommendations from civil society organisations for Tanzania's 2nd draft national REDD+ strategy and draft action plan. Tanzania Natural Resource Forum, Arusha, Tanzania. [online] URL: http://www.tnrf.org/files/REDD \% 20Strategy $\% 202 \% 20$ CSO $\% 20$ Feedback $\% 20$ Aug $\% 202012 \quad 30 \% 20$ August. pdf?utm_source $=$ Quarterly + Newsletter\&utm_campaign=bf0b38512dTNRF Quarterly Newsletter Issue 3103 2012\&utm medium= email

Tanzania Forestry Working Group (TFWG). 2009. Recommendations for the national strategy on reduced emissions from deforestation and forest degradation (REDD). Tanzania Natural Resource Forum, Arusha, Tanzania. [online] URL: http://www.tnrf.org/ node/21169

Tanzania Forestry Working Group (TFWG). 2010. Options for REDD in Tanzania: key design issues for the national REDD strategy. Tanzania Natural Resource Forum, Arusha, Tanzania. [online] URL: http://www.tnrf.org/node/21243?group=21123

United Nations Framework Convention on Climate Change (UNFCCC). 2008. Report of the Conference of the Parties on its thirteenth session, held in Bali from 3 to 15 December 2007. Part two: action taken by the Conference of the Parties at its thirteenth session. FCCC/CP/2007/6/Add.1, UNFCCC, Bonn, Germany.

United Nations Framework Convention on Climate Change (UNFCCC). 2011. Report of the Conference of the Parties on its sixteenth session, held in Cancun from 29 November to 10 December 2010. FCCC/CP/2010/7/Add.1, UNFCCC, Bonn, Germany.

United Republic of Tanzania (URT). 2010. The first draft national strategy for reduced emissions from deforestation and forest degradation $(R E D D+)$. Vice President's Office, Dar es Salaam, Tanzania. 
United Republic of Tanzania (URT). 2011. National strategy for reduced emissions from deforestation and forest degradation $(R E D D+)$ : executive summary. Vice President's Office, Dar es Salaam, Tanzania.

United Republic of Tanzania (URT). 2012. The second draft national strategy for reduced emissions from deforestation and forest degradation (REDD+). Vice President's Office, Dar es Salaam, Tanzania.

United Republic of Tanzania (URT). 2013a. Action plan for the implementation of the national strategy for reduced emissions from deforestation and forest degradation (REDD+). Vice President's Office, Dar es Salaam, Tanzania.

United Republic of Tanzania (URT). 2013b. National strategy for reduced emissions from deforestation and forest degradation $(R E D D+)$. Vice President's Office, Dar es Salaam, Tanzania.

Van der Werf, G. R., D. C. Morton, R. S. DeFries, J. G. J. Olivier, P. S. Kasibhatla, R. B. Jackson, G. J. Collatz, and J. T. Randerson. 2009. $\mathrm{CO}_{2}$ emissions from forest loss. Nature Geoscience 2:737-738. http://dx.doi.org/10.1038/ngeo671

Wertz-Kanounnikoff, S., and A. Angelsen. 2009. Global and national REDD+ architecture: linking institutions and actions. Pages 11-21 in A. Angelsen, editor. Realizing REDD+: national strategy and policy options. Center for International Forestry Research (CIFOR), Bogor, Indonesia. 
Appendix 1: Figure A1. Numbers of organizational actors agreeing and disagreeing with the five most divisive stances according to the structured survey data.

\section{Total numbers of agreements and disagreements}

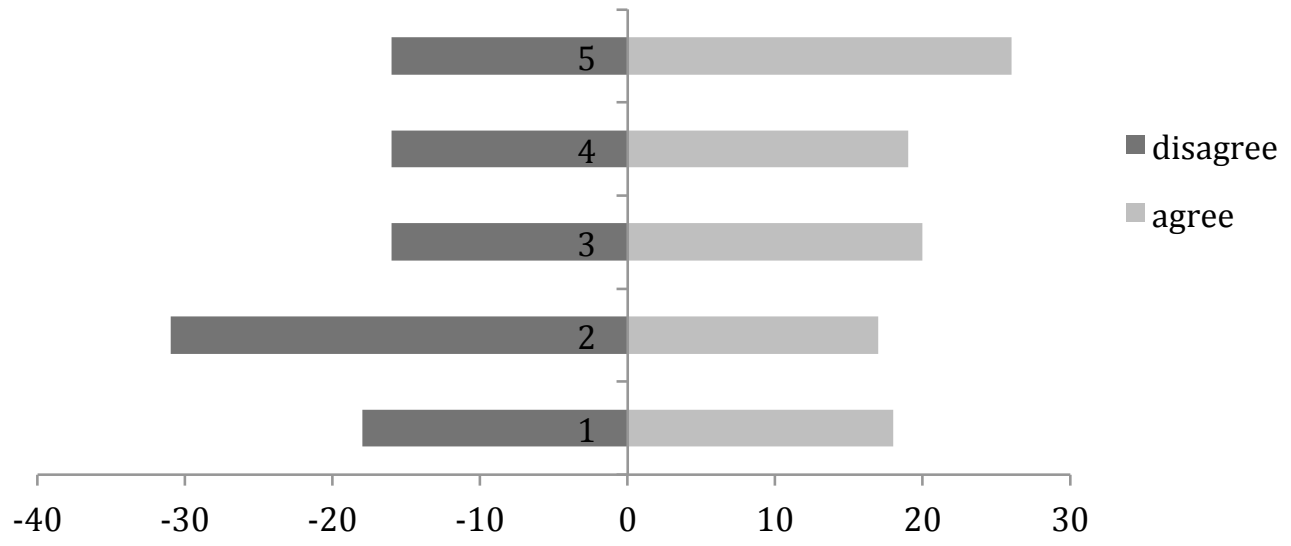

Key:

1. "REDD+ schemes should only be financed through funds."

2. "All REDD+ accounting and payments should go through the national governments."

3. "REDD+ benefits should reward large-scale industries for reducing forest emissions."

4. "REDD+ schemes developed with the sole objective to reduce $\mathrm{CO} 2$ emissions are likely to be in contrast with biodiversity conservation aims."

5. "Scientific experts dominate the national REDD+ policy discussion, at the expense of other relevant interests." 